\title{
Evaluation of Toxicological Risk Related to Presence of Lead and Cadmium in Moringa oleifera Lam. Leaves Powders Marketed in Cotonou (Benin)
}

\author{
Alain K. Aissi ${ }^{1,2}$, Elisabeth Yehouenou Pazou', Théodora A. Ahoyo1, Lauris Fah"1, \\ Brice Fanou', Luc Koumolou², Hornel Koudokpon', Clément Agbangla3, \\ Kissao Gnandi' ${ }^{4}$, Frédéric Loko ${ }^{1}$ Patrick A. Edorh ${ }^{2,5}$ \\ ${ }^{1}$ Research Laboratory in Applied Biology, Polytechnic School of Abomey-Calavi, University of Abomey-Calavi, \\ Cotonou, Benin \\ ${ }^{2}$ Laboratory of Toxicology and Environmental Health, Interfaculty Center of Formation and Research in \\ Environment for the Sustainable Development, University of Abomey-Calavi, Cotonou, Benin \\ ${ }^{3}$ Laboratory of Genetics, Faculty of Science and Technology, University of Abomey-Calavi, Cotonou, Benin \\ ${ }^{4}$ Laboratory of Management, Treatment and Valuation of Waste (GTVD), Faculty of Sciences, University of \\ Lome, Lome, Togo \\ ${ }^{5}$ Department of Biochemistry and Cellular Biology, Faculty of Science and Technology, University of \\ Abomey-Calavi, Cotonou, Benin \\ Email: ${ }^{*}$ alkaiss2ieme@gmail.com
}

Received 23 January 2014; revised 23 February 2014; accepted 5 March 2014

Copyright (C) 2014 by authors and Scientific Research Publishing Inc.

This work is licensed under the Creative Commons Attribution International License (CC BY).

http://creativecommons.org/licenses/by/4.0/

(c) (i) Open Access

\section{Abstract}

To evaluate lead and cadmium contamination in Moringa oleifera leaves powders marketed in Cotonou and health risks associated with its consumption, cross-sectional and analytical study were done from October $23^{\text {th }}, 2012$ to June $20^{\text {th }}, 2013$. Samples of Moringa powders were purchased at different outlets (health centers, supermarkets, pharmacy, etc.). Assays were performed by atomic absorption spectrophotometry after digestion according calcination method. $\mathrm{Pb}$ and $\mathrm{Cd}$ levels were compared with Codex Alimentarius standards, using the Student $t$ test. Daily Exposure Doses (DDE) and Hazard Quotients (HQ) specific to each contaminant were calculated using a conventional method. Results revealed that the mean concentration of lead for all samples $[1.526$ $\mathrm{mg} / \mathrm{kg}$ ) exceeded of about 5.08 times the maximum allowable limit whereas cadmium levels $(0.246 \mathrm{mg} / \mathrm{kg})$ was not statistically higher than the standard. The highest concentrations of $\mathrm{Pb}$ and Cd are respectively $4.263 \mathrm{mg} / \mathrm{kg}$ and $0.354 \mathrm{mg} / \mathrm{kg}$. Children are 2.3 to 3.8 times in greater danger

*Corresponding author.

How to cite this paper: Aissi, A.K., et al. (2014) Evaluation of Toxicological Risk Related to Presence of Lead and Cadmium in Moringa oleifera Lam. Leaves Powders Marketed in Cotonou (Benin). Food and Nutrition Sciences, 5, 770-778.

http://dx.doi.org/10.4236/fns.2014.59087 
than adults although all QD calculated are less than 1, reflecting that there is a low risk to consumers in general. For both metals, DJE specifically linked to the consumption of Moringa was less than $2 \%$ compared to other kinds of food intake. In conclusion, the current level of contamination (with lead and cadmium) of Moringa leaves powders marketed in Cotonou is not yet an alarming threat to consumers' health. However, care must be taken to reduce chemical pollution especially soils where these plants grow.

\section{Keywords}

Moringa oleifera; Lead; Cadmium; Hazard; Food Supplement

\section{Introduction}

The rapid development of knowledge on nutritional and medicinal properties (anti-immunosuppressive, antihyperglycemic, anti-hypertensive, antioxidant, antimicrobial, anti-anemic, anti-toxic, etc.) of Moringa oleifera leaves [1]-[7] promotes increasingly its use as food supplements [8]-[11]. In a study recently published by Aissi et al. [12], it appears that in Benin like most sub-Saharan Africa's countries [13], the production of these food supplements don't follow strictly the standards of Quality Assurance. Thus, the assessment of the microbiological quality performed on Moringa oleifera powders samples purchased from several outlets in Cotonou, revealed presence of abundant microbial flora such as Escherichia coli, coagulase-positive Staphylococci, yeasts, mould, etc. beyond allowable limits for human consumption [12]. The testing of a sterilization at low temperature $\left(50^{\circ} \mathrm{C}\right)$ for 24 hours has not helped to reduce the amount of total germs below the threshold of $5 \times 10^{4} \mathrm{CFU} / \mathrm{g}$, set as limit of unacceptability of this kind of the food [14]. Moreover, current regulations in Benin, through laws and decrees [15] regarding the production and sale of food supplements is insufficient for better regulate this business line predominantly occupied by non-governmental organizations (NGOs) and some small businesses. Thus, consumers including thousands of People Living with HIV (PLHIV) malnourished under the weight of the disease and the influence of antiretrovirals drugs [16] are certainly exposed to a real danger. In this context, it is important to stimulate the judicious intervention at every level of the production chain of said powders in order to ensure on the market safe products [17] [18]. But before that, the complete identification of all other possible dangers associated with the consumption of said powders of Moringa oleifera is required, especially from the toxicological viewpoint. For acute and subchronic toxicity, Awodele et al. [19] noted the scarcity of documented data on these issues, have undertaken in vivo experiments which showed that safety of aqueous extracts of Moringa oleifera is relatively acceptable. But according to Isuita and Ibeh [20], it is imperative to check this conclusion by more detailed studies. The present study aims to evaluate lead and cadmium concentration in Moringa oleifera powders marketed as food supplement in Cotonou and characterizes consumers' health risks. The choices of these two heavy metals are due partly by their highly toxic nature [21] when exceeding a certain threshold in food [22] [23]. On the other hand, this choice is explained by the fact that several studies conducted in Benin report currently a growing threat of bioaccumulation of these toxic in some drinking water [24], freshwater fish [25] [26], vegetables [27] [28] and other food products [29], although fawned by the people.

\section{Material and Methods}

\subsection{Study Area}

This study is cross-sectional and analytical. It took place at Cotonou in Benin (Figure 1) from October $23^{\text {th }}$, 2012 to June $20^{\text {th }}$, 2013. Cotonoucity was chosen because of its status as economic capital, where many manufacturers (national and foreign) of food supplements come to sell their products. This allows to having a fairly diverse range of samples sold in the country.

\subsection{Collection of Biological Material}

The biological material consists in samples of Moringa oleifera leaves powders (Figure 2) coming from different 


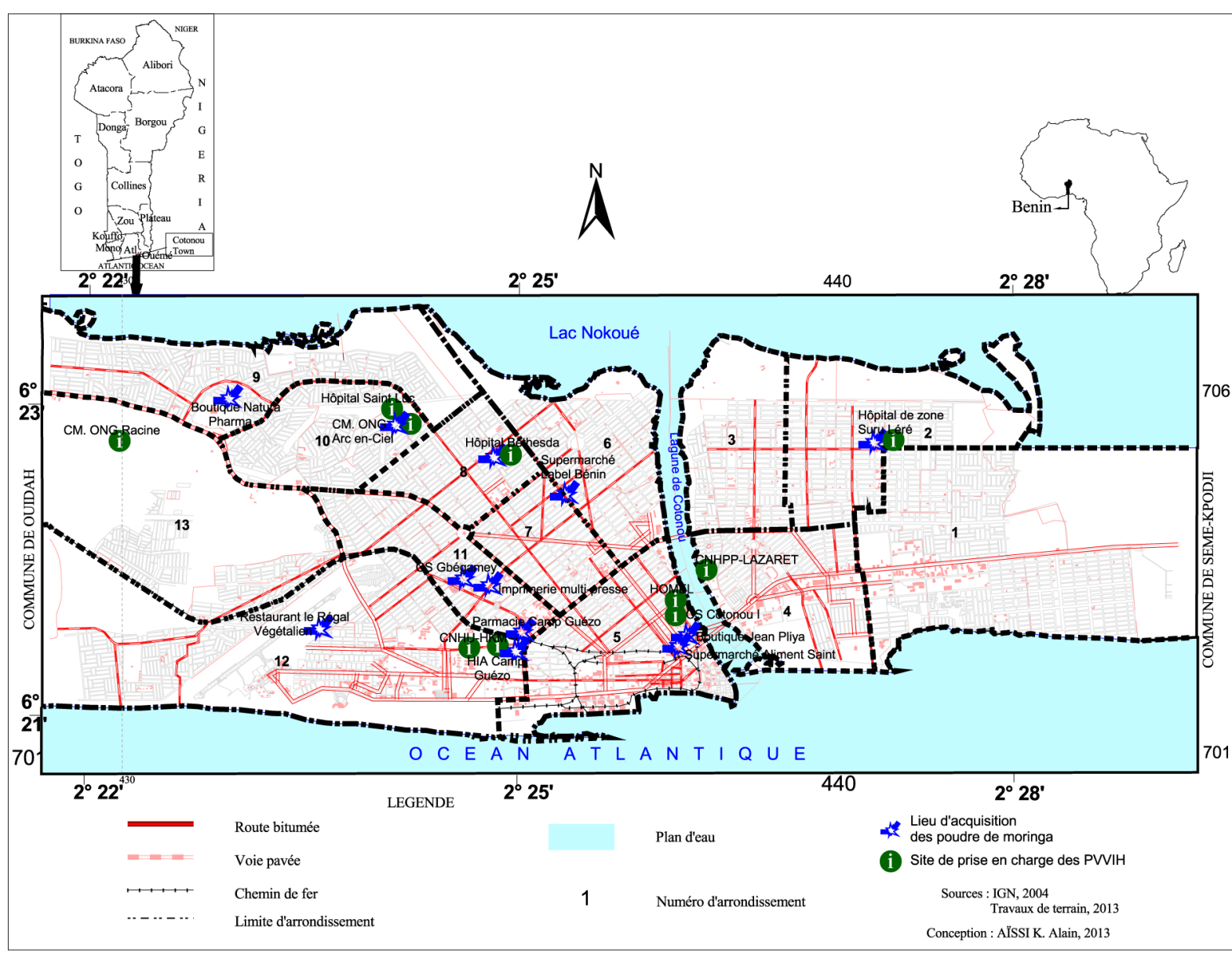

Figure 1. Moringa oleifera leaves powders acquisition location in Cotonou.

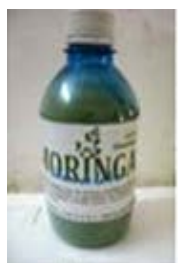

E1

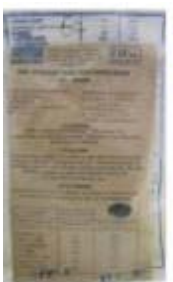

E7

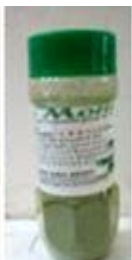

E2

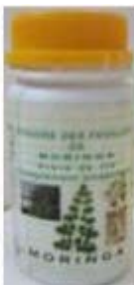

E8

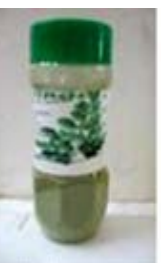

E3

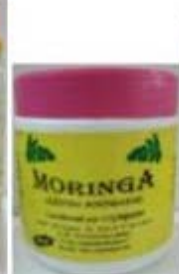

E9

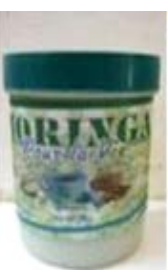

E4

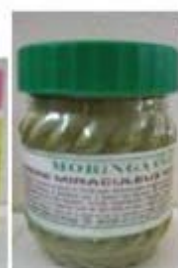

E10

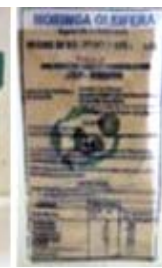

E5

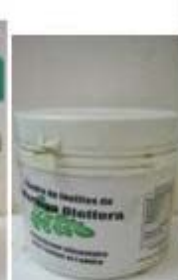

E11

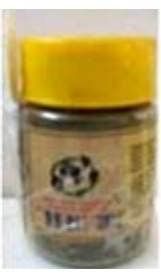

E6

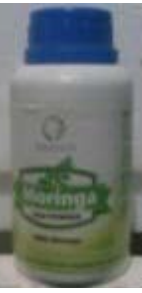

E12

Figure 2. Sample of each range of Moringa oleifera leaves powders purchased at Cotonou.

manufacturers (national or foreign) which package them in various packaging such as bags, boxes, envelopes. Collection has consisted to go through all the sites of care of PLHIV accredited by the National Programme for the Fight against AIDS and most other outlets (supermarkets, shops, drugstores, health centers) where patients 
interviewed during a preliminary investigation [16] go often get supply in food supplement. In each of these outlets, when Moringa was available, two samples of the powders were purchased in the stock found. In total, 24 samples were collected and transported to the laboratory in their original packaging. Identification codes have been assigned by order according to the place of supply namely: samples E1 (Hospital of Area of Suru Lere), E2 (Medical Center Arc-en Ciel), E3 (Bethesda Hospital), E4 (Printing Multipresse) E5 (Health Center of Gbégamey), E6 (restaurant Le Régal Végétalien), E7 (NGO Jeunesse Sans Frontière), E8 (Supermarket Label Benin), E9 (shop Jean Pliya), E10 (Supermarket Aliment sain), E11 (pharmacy Camp Guézo), E12 (shop Natura Pharma).

\subsection{Methods of Laboratory Analysis}

Analyzes were conducted at the Laboratory of Treatment and Valuation of Waste located at University of Lome, Togo. For each sample, $2 \mathrm{~g}$ were mineralized according to calcination method. The collected ashes have been wetted with $5 \mathrm{ml}$ of distilled water and then was added $1 \mathrm{ml}$ of concentrated nitric acid. All these mixtures were carried in a sand bath at $50^{\circ} \mathrm{C}$ until complete disappearance of water and acid. The digests were collected in $5 \mathrm{ml}$ of water and filtered before assays (lead and cadmium) with an atomic absorption spectrophotometer (Thermo Orion assisted brand Solaar software S2) after a regular calibration of the device.

\subsection{Statistical Data Processing}

Statistical analysis consisted in comparing each metal levels and the means concentrations of all samples with the maximum permissible limits according to Codex Alimentarius [23]. For this, comparison test of Student was performed at significance level of $5 \%$ using software Statistica 6. Proportions were calculated and graphs were done with Excel 2007. Bioconcentration factors were calculated by dividing lead and cadmium contents by corresponding standards values. In addition, the Daily Doses of Exposure (DDE) and Hazard Quotients (HQ) for each of the two metals were calculated using the conventional approach invented by Academy of Sciences in United States [30] and adopted by the Health Monitoring Institute of France [31]. Thus, considering children exposureby lead, the following formulas are used:

1) $\mathrm{DDE}_{\text {child }}=\mathrm{DDE}_{\mathrm{e}}+\mathrm{DDE}_{\mathrm{al}}$

2) $\operatorname{DDE}_{\mathrm{e}}=\left(\mathrm{Q}_{\mathrm{e}} \times \mathrm{C}_{\mathrm{e}}\right) / \mathrm{BW}$

3) $\mathrm{HQ}_{\text {child }}=\mathrm{DDE}_{\text {child }} / \mathrm{TDD}$ where:

- $\quad \mathrm{TDD}=$ tolerable daily dose in $\mu \mathrm{g} / \mathrm{kg} / \mathrm{day}$ (of lead)

- $\mathrm{DDE}_{\text {child }}=$ total daily dose of exposure for children $(\mu \mathrm{g} / \mathrm{kg} / \mathrm{day})$

- $\mathrm{DDE}_{\mathrm{e}}=$ daily dose of exposure in lead provided by the consumption of Moringa leaves powders $(\mu \mathrm{g} / \mathrm{kg} / \mathrm{day})$

- $\mathrm{DDE}_{\mathrm{al}}=$ daily dose of exposure in lead provided by the generaldiet $(\mu \mathrm{g} / \mathrm{kg} / \mathrm{day})$

- $Q_{\mathrm{e}}$ : average quantity of Moringa leaves powders consumed by a child or an adult (kg/day)

- $\mathrm{C}_{\mathrm{e}}$ : content of lead found in the analyzed powders $(\mu \mathrm{g} / \mathrm{kg})$

- BW: body weight of consumer (child or adult) in kg.

\section{Results and Discussion}

\subsection{Results}

\subsubsection{Heavy Metals Contents in Samples Powders Analyzed}

1) Lead content

Assays performed on Moringa oleifera powders showed that $58.33 \%$ of selected samples had lead levels exceeding the standard of $0.3 \mathrm{mg} / \mathrm{kg}$ set by Codex Alimentarius applicable to foodstuffs (leafy vegetables particular) according (Codex Standard 193-1995). The overall average of lead concentrations for all samples was 1.526 $\mathrm{mg} / \mathrm{kg}$. This average is significantly greater than the allowable standard $(\mathrm{p}=0.015<0.05)$ with a bioconcentration factor of about 5.08. The range of values found was from 0.01 to $4.263 \mathrm{mg} / \mathrm{kg}$ (Figure 3).

2) Cadmium content

For cadmium, the overall average concentrations of this metal in all samples were $0.246 \mathrm{mg} / \mathrm{kg}$. The difference between this average and acceptable standard $(0.2 \mathrm{mg} / \mathrm{kg})$ was not statistically significant $(\mathrm{p}=0.066>$ 0.05), although in absolute terms, $75 \%$ of samples had cadmium levels above this limit of $0.2 \mathrm{mg} / \mathrm{kg}$. The highest concentration of cadmium is $0.354 \mathrm{mg} / \mathrm{kg}$ (i.e. a bioconcentration factor less than 2) and the lowest 
was $0.093 \mathrm{mg} / \mathrm{kg}$ (Figure 4).

\subsubsection{Calculation of Toxicity Indices for Both Metals Studied}

1) Daily Dose Exposure and Hazard Quotient for lead

The survey previously carried out on the sites of care for PLHIV [16] enhanced by the information mentioned on the packaging of Moringa powders (Figure 2) were use to estimate at $0.040 \mathrm{~kg} /$ day, the average quantity (Qe) of the product consumed by both child and adult. Moreover, according to French Agency for Food Safety [31], daily dose of lead exposure via the general diet (DDE al) is estimated at $2.60 \mathrm{mg} / \mathrm{kg} / \mathrm{day}$ for children weighing in average $20 \mathrm{~kg}$ bw. The tolerable daily dose (TDD) of this metal is $3.5 \mu \mathrm{g} / \mathrm{kg} / \mathrm{day}$ [32]. Thus, since the lead average content (Ce) found in all samples was $1.526 \mathrm{mg} / \mathrm{kg}$, the value of $2.6031 \mathrm{mg} / \mathrm{kg}$ was obtained as total DDE for this category of consumers (children) while in adults, the DDE calculated is equal to $0.6808 \mathrm{mg} / \mathrm{kg}$. As for hazard quotients (HQ), they are respectively equal to 0.744 (for child) and 0.195 (for adults) from Table 1 .

2) Daily Dose of Exposure and Hazard Quotient for Cadmium

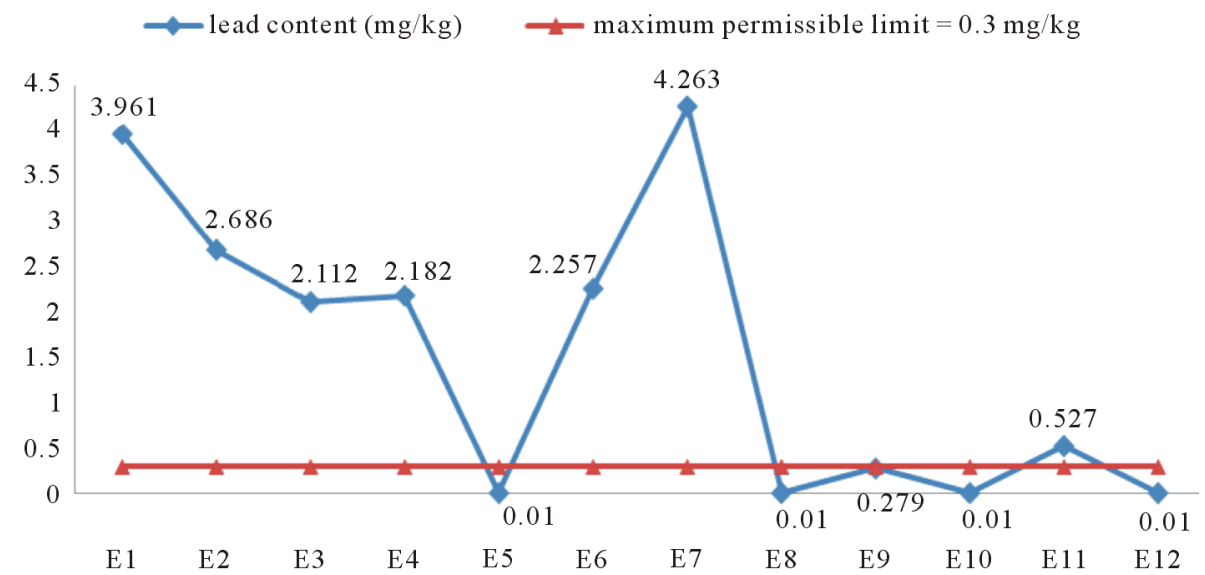

Figure 3. Comparison of lead levels in samples of Moringa oleifera Lam. powders with toxicological standards of Codex Alimentarius.

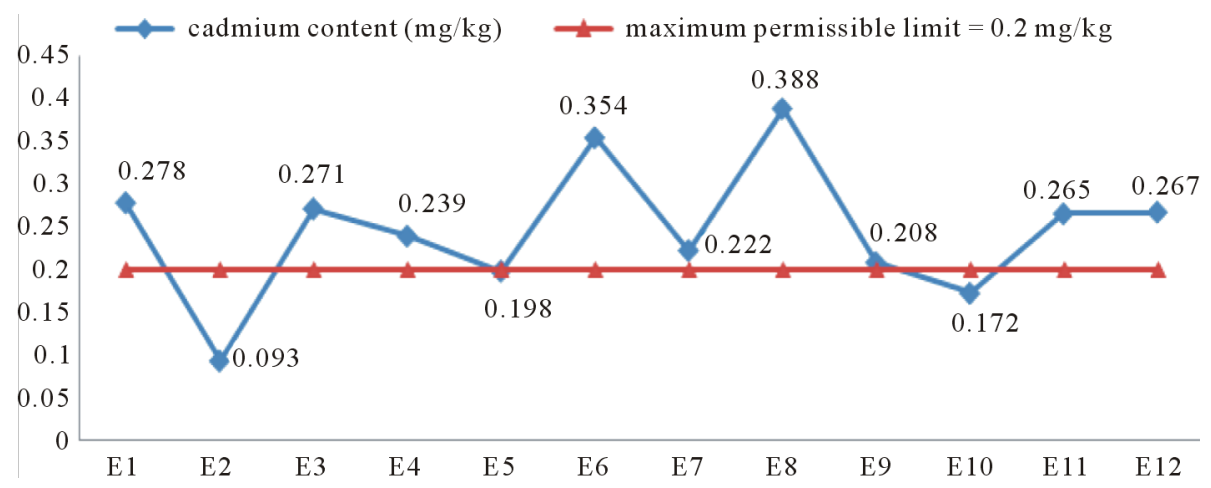

Figure 4. Comparison of cadmium levels in samples of Moringa oleifera Lam. powders with toxicological standards of Codex Alimentarius.

Table 1. Results of calculation of DDE and HQ related on lead.

\begin{tabular}{ccccccccc}
\hline Consumer & $\mathrm{BW}$ & $\mathrm{Q}_{\mathrm{e}}$ & $\mathrm{C}_{\mathrm{e}}$ & $\mathrm{DDE}_{\mathrm{e}}$ & $\mathrm{DDE}_{\text {al }}$ & $\mathrm{DDE}_{\text {child/adult }}$ & $\mathrm{TDD}$ & $\mathrm{HD}_{\text {child/adult }}$ \\
\hline Child & 20 & 0.04 & 1.526 & 0.0031 & 2.6 & 2.6031 & 3.5 & 0.744 \\
Adult & 77 & 0.04 & 1.526 & 0.0008 & 0.68 & 0.6808 & 3.5 & 0.195 \\
\hline
\end{tabular}

${ }^{1)} \mathrm{DDE}_{\text {child }}=\mathrm{DDE}_{\mathrm{e}}+\mathrm{DDE}_{\mathrm{al}} ;{ }^{2)} \mathrm{DDE}_{\mathrm{e}}=\left(\mathrm{Q}_{\mathrm{e}} \times \mathrm{C}_{\mathrm{e}}\right) / \mathrm{BW} ;{ }^{3)} \mathrm{HQ}_{\text {child }}=\mathrm{DDE}_{\text {child }} / \mathrm{TDD}$. 
Regarding cadmium,

- $\mathrm{Q}_{\mathrm{e}}=0.040$ (kg/day) (for children and adults),

- $\mathrm{DJE}_{\mathrm{al}}=0.38 \mu \mathrm{g} / \mathrm{kg} / \mathrm{day}$ (for children) et $0.16 \mu \mathrm{g} / \mathrm{kg} / \mathrm{day}$ (for adults),

- $\quad \mathrm{DJT}=0.5 \mu \mathrm{g} / \mathrm{kg} / \mathrm{day}$ (for children and adults),

- $\mathrm{C}_{\mathrm{e}}=0.246 \mathrm{mg} / \mathrm{kg}$.

Thus, there is obtained according to Table 2.

- $\mathrm{DDE}_{\text {child }}=0.3805 \mathrm{mg} / \mathrm{kg}$ (for children),

- $\quad \mathrm{DDE}_{\text {adult }}=0.1601 \mathrm{mg} / \mathrm{kg}$ (for adults),

- $\mathrm{HQ}=0.761$ (for children) and 0.320 (for adults).

\subsection{Discussion}

\subsubsection{Presence of Heavy Metals in Powders of Moringa oleifera}

Excessive presence of inorganic contaminants, including heavy metals in food constitutes a risk to consumer health [22]. In this study, the average concentration of lead $(1.526 \mathrm{mg} / \mathrm{kg})$ in the Moringa leaves powders sold in Cotonou, is about 5.08 times the maximum permissible limit $(0.3 \mathrm{mg} / \mathrm{kg})$ according to Codex Alimentarius Commission charged for setting toxicological standards for food products [23]. This bioconcentration factor (5.08) is two times lower than that found by Dougnon et al. [33] in some vegetable leaves such as Solanummacrocarpon highly consumed in Cotonou (Benin). Limmatvapirat et al. [34] had observed in Moringa leaves from seven different locations (in Thailand), lead values almost similar to those found in our samples which are between 0.963 and $3.459 \mathrm{mg} / \mathrm{kg}$ with an average of $1.753 \mathrm{mg} / \mathrm{kg}$. Regarding cadmium average concentration of $(0.246 \mathrm{mg} / \mathrm{kg})$ found in our samples, the non-significance of the difference with Codex maximum limit $(0.2$ $\mathrm{mg} / \mathrm{kg}$ ) did not systematically removes the danger which could be, if no precautions are taken to curb this bioaccumulation in the Moringa plants. However, this finding is consistent with assessment results of cadmium in some food products in Benin [29] and in Moringa oleifera leaves in Thailand [34], which respectively showed many values below the threshold of $0.2 \mathrm{mg} / \mathrm{kg}$. Indeed, the main source of trace metals in Moringa oleifera leaves is usually related to chemical pollution of soil where plants are cultivated [18]. Several authors whose Vikashni et al. [35] showed that Moringa oleifera seeds or roots readily absorb heavy metals such us lead, cadmium, zinc, copper, chromium compared to many other plant species. The share of atmospheric pollution related toexhaustgas in this bioaccumulation of heavy metals in Moringa leavesis, however, notto overlook [34].

\subsubsection{Health Risks Incurred by Consumers}

Exceeding the maximum allowable standards regarding lead, indicates existence of a real danger on this metal. The danger from cadmium is not less to be considered in so far as minimum of $75 \%$ of samples have a concentration above Codex Alimentarius standard. These two metals are ranked among the chemicals for which adverse effects are observed only beyond a certain administered dose [32]. Using the toxicological reference values available in the database of WHO, AFSSA, INERIS [32] and defined from studies of dose-response relationships, we were able to calculate the DDE and HQ that characterize more or less, the health risks to consumers. Indeed, the total daily dose of lead exposure calculated for child $(2.6030 \mathrm{mg} / \mathrm{kg} / \mathrm{day})$ and adult (2.6009 $\mathrm{mg} / \mathrm{kg} /$ day) does not exceed the tolerable daily dose (TDD) of this substance which is $3.5 \mathrm{mg} / \mathrm{kg} / \mathrm{day}$ according to WHO or $3.6 \mathrm{mcg} / \mathrm{kg} /$ day according to the National Institute of Public Health and the Environment of the Netherlands [32]. The hazard quotients are all also, less than 1 indicating a low risk for all consumers considered although the risk to child is two times greater than that of adults $(0.761$ against 0.320$)$. This interpretation is the same regarding the risk related to cadmium although, at this metal level, it is important to note that the DDE is much lower. Hence, a seemingly higher risk (0.761 and 0.320) compared to that of lead. Let us note that daily dose of exposure to lead and cadmium specifically related to the consumption of Moringa oleifera powders are

Table 2. Results of calculation of DDE and HQ related on cadmium.

\begin{tabular}{cccccccccc}
\hline Consumer & BW & $\mathrm{Q}_{\mathrm{e}}$ & $\mathrm{C}_{\mathrm{e}}$ & $\mathrm{DDE}_{\mathrm{e}}$ & $\mathrm{DDE}_{\mathrm{al}}$ & $\mathrm{DDE}_{\text {child/adult }}$ & $\mathrm{TDD}$ & $\mathrm{HD}_{\text {child/adult }}$ \\
Child & 20 & 0.04 & 0.246 & 0.0005 & 0.38 & 0.3805 & 0.5 \\
Adult & 77 & 0.04 & 0.246 & 0.0001 & 0.16 & 0.1601 & 0.5 \\
\hline
\end{tabular}


extremely low in comparison with those provided by the general diet. They represent less than $0.2 \%$ of the total dietary intake of lead and cadmium, whatever the categories of consumers (child or adult). Also, note that uncertainties may remain in the determination of ECD in case of inaccuracy of some data such as the average weight of a child and an adult, the average quantity of Moringa powders consumed daily by children or adults, the average quantity of lead or cadmium provided by the general diet. It is therefore important to investigate in the future to determine accurately in Benin, all these missing data for more relevant monitoring of health risks incurred by the population.

\section{Conclusion}

This study has allowed to knowing the content of two dreaded metal pollutants to human health. Indeed, lead and cadmium are found at concentrations ranging respectively from 0.01 to $4.263 \mathrm{mg} / \mathrm{kg}$ and from 0.093 to $0.354 \mathrm{mg} / \mathrm{kg}$. The mean of bioaccumulation factor of lead is equal to 5.08 while the mean concentration of cadmium did not significantly exceed the standards of edibility set in the Codex Alimentarius. Children are at least twice more in danger than adults, despite the low overall risk for all consumers. Moringa oleifera, consumed as food supplement contributes less than $2 \%$ contamination with lead and cadmium foodborne. The current level of contamination of powdered Moringa sold in Cotonou is not yet an alarming threat to the health of consumers. However, some actions must be undertaken in an ecosystemic approach to human health, to curb chemical pollution especially soils where these plants grow.

\section{Acknowledgements}

Many thanks to Engineers of Quality Control Laboratory of Water and Food (LNCQEA) to the National Directorate of Public Health (Benin) particularly Mr. Elias Pognon. Recognition equally to researchers of the Laboratory of Treatment and Valuation of Waste located at the University of Lomé (Togo) directed by Prof. GnandiKissao as well as Dr. Jean Robert Klotoé, Dr. Patient Guédénon and Dr. Victorien Dougnon.

\section{References}

[1] Pari, L. and Kumar, N.A. (2002) Hepatoprotective Activity of Moringa oleifera on Antitubercular Drug-Induced Liver Damage in Rats. Journal of Medicinal Food, 5, 171-177. http://dx.doi.org/10.1089/10966200260398206

[2] Nambiar, V.S. (2006) Potentiel nutritionnel des feuilles de Moringa: une perspective indienne. Moringa et autres végétaux à fort potentiel nutritionnel. Stratégies, normes et marchés pour un meilleur impact sur la nutrition en Afrique, Accra, 16-18 Novembre 2006, 7. http://www.moringanews.org/doc/FR/Articles/Vanisha_Nambiar_text_FR.pdf

[3] Anwar, F., Latif, S., Ashraf, M. and Gilani, A.H. (2007) Moringa oleifera: A Food Plant with Multiple Medicinal Uses. Phytotherapy Research, 21, 17-25. http://dx.doi.org/10.1002/ptr.2023

[4] Bukar, A., Uba, A. and Oyeyi, T.I. (2010) Antimicrobial Profile of Moringa oleifera Lam. Extract against Some Food Borne Microorganisms. Bayero Journal of Pure and Applied Sciences, 3, $43-48$. http://dx.doi.org/10.4314/bajopas.v3i1.58706

[5] Santos, A.F., Argolo, A.C., Paiva, P.M. and Coelho, L.C. (2012) Antioxidant Activity of Moringa oleifera Tissue Extracts. Phytotherapy Research, 26, 1366-1370. http://dx.doi.org/10.1002/ptr.4591

[6] Abou-Elezz, F.M.K., Sarmiento-Franco, L., Santos-Ricalde, R. and Solorio-Sanchez, J.F. (2012) The Nutritional Effect of Moringa oleifera Fresh Leaves as Feed Supplement on Rhode Island Red Hen Egg Production and Quality. Tropical Animal Health and Production, 44, 1035-1040. http://dx.doi.org/10.1007/s11250-011-0037-5

[7] Tété-Benissan, A., Quashie, M.L.A., Lawson-Evi, K., Gnandi, K., Kokou, K. and Gbeassor, M. (2013) Influence of Moringa oleifera Leaves on Atherogenic Lipids and Glycaemia Evolution in HIV-Infected and Uninfected Malnourished Patients. Journal of Applied Biosciences, 62, 4610-4619. http://dx.doi.org/10.4314/jab.v62i0.86072

[8] Saint Sauveur, A. and Broin, M. (2006) L'utilisation des feuilles de Moringa oleifera Lam. contre les carences alimentaires: un potentiel encore peu valorisé. Moringa et autres végétaux à fort potentiel nutritionnel. Stratégies, normes et marchés pour un meilleur impact sur la nutrition en Afrique, Accra, 16-18 Novembre 2006.

[9] Ahouansou, N. (2009) Les potentialités nutritionnelles et médicinales du Moringa oleifera en vue de l'amélioration de l'état sanitaire des PVVIH. $2^{\text {èmes }}$ Journées Scientifiques Béninoises sur le VIH/SIDA, Cotonou, 24 au 27 Novembre 2009.

[10] Attinsounon, A., Pourteau Adjahi, L.H., Dako, C. and Ahouansou, N. (2008) The Moringa Tree. A Tree for Nutrition and Income Generation of People Living with HIV (PLH) in Benin. AIDS 2008-XVII International AIDS Conference. 
http://www.iasociety.org/Abstracts/A200717835.aspx

[11] Tété-Benissan, A., Quashie, M.L.A., Lawson-Evi, K., Kokou, K. and Gbeassor, M. (2013) Récupération nutritionnelle chez les sujets malnutris VIH positifs et VIH négatifs après utilisation de feuilles de Moringa oleifera Lam. Journal of Animal \& Plant Sciences, 15, 2184-2199.

[12] Aïssi, A.K., Kougblénou, S., Dougnon, T.V., Tchiakpe, E., Bankolé, H., Klotoé, J.R., Edorh, A.P. and Loko, F. (2013) Evaluation de la qualité sanitaire des poudres de feuilles de Moringa oleifera Lam. commercialisées au profit des Personnes Vivant avec le VIH à Cotonou (Bénin). International Journal of Biological and Chemical Sciences, 7, 1461-1473.

[13] Diouf, B., Tandem, A.E.C. and Saint Sauveur, A. (2006) Le marché des compléments alimentaires à Dakar Moringanews. http://www.moringanews.org/documents/marchedakar.doc

[14] CECMA (Comité sur l’Elaboration des Critères Microbiologiques dans les Aliments) (2009) Lignes directrices et normes pour l'interprétation des résultats analytiques en microbiologie alimentaire. http://www.mapaq.gouv.qc.ca/NR/rdonlyres/6B9A8992-396D-45CD-8841-EFD19E3D7C8/0/recueil.pdf

[15] Lawogni, A., Sadeleer, N., Amouzoun, A., Bansouand, C. and Ahonoukoun, S.B. (2002) Droit de l'environnement au Bénin, Code officieux de l'environnement. Hygiène et Santé. http://www.bj.refer.org/benin ct/Droit/site1 2/ docPDF/texte6.pdf

[16] Aïssi, A.K., Hounto Ogouyemi, A., Jonhson, R.C., Kplakatcha, S., Dougnon, T.V., Tchiakpe, E., Klotoé, J.R., Edorh, A.P. and Loko, F. (2013) Frequency Deficiencies in Trace Elements and Correlations with the Degree of Immunosuppression in People Living with HIV in Cotonou (Benin). International Journal of Biosciences, 3, 58-67. http://dx.doi.org/10.12692/ijb/3.4.58-67

[17] OMS (Organisation Mondiale de la Santé) (2000) Principes méthodologiques généraux pour la recherche et l’évaluation relatives à la médecine traditionnelle. Genève. who.int/medicinedocs/en/d/Js4929f

[18] Saint Sauveur, A. and Broin, M. (2010) Produire et transformer les feuilles de moringa. http://www.anancy.net/documents/file_fr/moringawebFR.pdf

[19] Awodele, O., Oreagba, I.A., Odoma, S., da Silva, J.A. and Osunkalu, V.O. (2012) Toxicological Evaluation of the Aqueous Leaf Extract of Moringa oleifera lam Moringaceae. Journal of Ethnopharmacology, 139, 330-336. http://dx.doi.org/10.1016/j.jep.2011.10.008

[20] Isitua, C.C. and Ibeh, I.N. (2013) Toxicological Assessment of Aqueous Extract of Moringa oleifera and Caulis bambusae Leaves in Rabbits. Journal of Clinical Toxicology, S12, 4.

[21] Edorh, A.P., Agonkpahoun, E., Gnandi, K., Guédénon, P., Koumolou, L., Amoussou, C., Ayedoun, A., Boko, M., Gbeassor, M., Rihn, H. and Creppy, E. (2009) An Assessment of the Contamination of Achatina achatina by Toxic Metals in Okpara Village. International Journal of Biological and Chemical Sciences, 3, 1428-1436.

[22] European Food Safety Authority (2009) Scientific Opinion of the Panel on Contaminants in the Food Chain on a Request from the European Commission on Cadmium in Food. The European Food Safety Authority Journal, 980, 1-139.

[23] Food and Agriculture Organization and World Health Organization (2013) Norme generale codex pour les contaminants et les toxines presents dans les produits de consommation humaine et animale. Codex Standard 193-1995, Adopté en 1995. Révisé en 1997, 2006, 2008, 2009, 2010 par la Commission du Codex alimentarius, 1-49.

[24] Elegbede, B., Edorh, A.P., Aïssi, A.K., Koumolou, L., Kaki, C., Guedenon, P., Koudovo, K., Montcho, S. and Boko, M. (2012) Blood Lead Levels and Bio-markers of Lead Toxicity via the Consumption of Drinking Water in Kerou (Benin) in Watershed of the Niger. International Journal of Environmental Protection, 2, 10-15.

[25] Hounkpatin, A.S.Y., Edorh, A.P., Sahidou, S., Gnandi, K., Koumolou Luc, L., Agbandji, L., Aïssi, A.K., Gouissi, M. and Boko, M. (2012) Assessment of Exposure Risk to Lead and Cadmium via Fish Consumption in the Lacusrian Village of Ganvié in Benin Republic. Journal of Environmental Chemistry and Ecotoxicology, 4, 1-10.

[26] Guédénon, P., Edorh, A.P., Kaki, C., Yehouenou, A.P.E., Gnandi, K., Montcho, S., Hounkpatin, A., Koumolou, L. and Boko, M. (2012) Arsenic, Cadmium, Copper and Lead Accumulation in Water, Sediments and Fish Species of Oueme River in Bonou. British Journal of Pharmacology and Toxicology, 3, 13-20.

[27] Dougnon, V., Edorh, P., Bankolé, H., Dougnon, J., Klotoé, J.R., Fréderic, L., Creppy, E. and Boko, M. (2013) Presence of Lead in Leaves of Solanum macrocarpon Cultivated in Cotonou (Benin): Role of Poorly Composted Poultry Manure. Comptes Rendus de Biologie, 336, 261-264. http://dx.doi.org/10.1016/j.crvi.2013.04.006

[28] Koumolou, L., Edorh, P., Montcho, S., Aklikokou, K., Loko, F., Boko, M. and Creppy, E.E. (2013) Health-Risk Market Garden Production Linked to Heavy Metals in Irrigation Water in Benin. Comptes Rendus de Biologie, 336, 278-283. http://dx.doi.org/10.1016/j.crvi.2013.04.002

[29] Fangnon, B., Tohozin, A.Y., Guedenon, P. and Edorh, A.P. (2012) Conservation Des Produits Agricoles Et Accumulation Des Metaux Lourds Dans Les Produits Vivriers Dans Le Departement Du Couffo (Benin). Journal of Applied Biosciences, 57, 4168-4176. 
[30] Aïssi, A.K., Edorh, A.P., Degbey, C., Guedenon, P., Segbo, J., Hounkpatin, A.S.Y., Boco, M. and Loko, F. (2013) Assessment of Risk Connected to the Management of Effluents from Abomey-Calavi and Sô-Ava Laboratories. British Journal of Applied Science \& Technology, 3, 307-319.

[31] Ricoux, C. and Gasztowtt, B. (2005) Evaluation des risques sanitaires lies a l'exposition de forts consommateurs produits de la peche de riviere contamines par des toxiques de l'environnement. Document De Travail, France, p. 65.

[32] French National Instiute for Industrial Environment and Risks (2009) Point sur les Valeurs Toxicologiques de Reference (VTR). Rapport d'étude No. DRC-08-94380-11776C du 17/03/2009, p. 62.

[33] Dougnon, T.V., Edorh, P.A., Bankolé, H.S., Dougnon, T.J., Montcho, S.A., Hounkpatin, A.S.Y., Gouissi, M., Sossou, B., Boko, M. and Creppy, E.E. (2012) Evaluation of the Toxicological Quality of the Leaves of Solanum macrocarpum L. Cultivated with the Chicken's Droppings and Water of Marsh at Cotonou (Benin). Journal of Research in Environmental Science and Toxicology, 1, 1-6.

[34] Limmatvapirat, C., Limmatvapirat, S., Charoenteeraboon, J. and Phaechamud, T. (2013) Inductively Coupled Plasma Mass Spectrometric Determination of Heavy Metals in Moringa oleifera Lam. Leaves. Research Journal of Pharmaceutical, Biological and Chemical Sciences, 4, 161-168.

[35] Vikashni, N., Matakite, M., Kanayathu, K. and Subramanium, S. (2012) Water Purification Using Moringa oleifera and Other Locally Available Seeds in Fiji for Heavy Metal Removal. International Journal of Applied Science and Technology, 2, 125-129. 